\title{
İskemik Önkoşullamanın Sporcu Performansına Etkisi Derleme Çalışması
}

\author{
Selin BİÇER BAİKOĞLU ${ }^{1 *}$ \\ ${ }^{1}$ Ístanbul Üniversitesi- Cerrahpaşa, Spor Bilimleri Fakültesi, https://orcid.org/ 0000-0002-6036-8945
}

Derleme

Gönderi Tarihi: 10.05.2019
Kabul Tarihi: 21.06.2019
DOI: $10.30769 /$ usbd 562669

Online Yayın Tarihi: 30.06.2019

\section{$\ddot{O} \mathbf{z}$}

Sporcuların egzersiz performanslarını arttırmaya yönelik çok sayıda bilimsel uygulama, veri ve öneriler ileri sürülmesine rağmen son zamanlarda bu konuda yapılan araştırmalar arasında en merak uyandıran olanı İskemik Önkoşullamadır (İÖK). Bir veya birden daha fazla kısa süreli olan iskemik periyotlarından sonra ileriki dönemlerde daha uzun süreli gerçekleșecek olan iskemik periyotlara karşı hücre, doku veya organı koruyan mekanizmaya İskemik önkoşullama denilmektedir. Yapılmış olan birçok çalıșmada iskemik önkoşullamanın sporcularda laboratuvar ortamında kas gücü ve kinematiği ile ilișkisinin etkileri ortaya konulmaya çalışılmasına rağmen, akut etkileri konusunda farklı bulgu ve sonuçlar ortaya konmuştur. Bu doğrultuda çalışmamızın amacı İÖ ${ }_{K}^{\prime}$ nın egzersiz kapasitesi ya da egzersiz performansı üzerine sağladığı katkıyı ve oluşabilecek fizyolojik tepkileri inceleyen çalışmaların bir bütün halinde toplanarak özetlenmesidir. Ayrıca İÖK'nın gelecekteki spor uygulamalarındaki kullanımına yönelik çalışmalar için tavsiyelerde bulunmaktır.

Anahtar kelimeler: İskemi, reperfüzyon, iskemik önkoşullama, egzersiz, performans.

\section{The Effect of Ischemic Preconditioning on Athletes Performance A Meta-Analysis}

\begin{abstract}
Although a large number of scientific practices, data and recommendations for increasing athletes' exercise performances have been put forth in recent years, the most gripping one among them has been about Ischemic Preconditioning. Ischemic Preconditioning refers to the mechanism that protects cells, tissues or organs against ischemic periods that first occur in the short-term, and then continue to occur in the long-term ischemic periods. Although current studies have attempted to reveal the effects of relationships between ischemic preconditioning and athletes' muscle force and kinematic in laboratory settings, different findings and results have been found in terms of its acute effects. The aim of the study is to summarize all the research and studies that have examined the contributions of IPC on exercise capacity or performances, and the possible physiological reactions. Additionally, implications are made about the use of IPC in sports in the future.
\end{abstract}

Keywords: Ischemia, reperfusion, ischemic preconditioning, exercise, performances.

* Sorumlu Yazar: Selin BAIKOĞLU (selinbaikoglu@gmail.com) 


\section{GíRiş}

Sporcuların egzersiz performanslarını arttırmaya yönelik çok sayıda bilimsel uygulama, veri ve öneriler ileri sürülmesine rağmen son zamanlarda bu konuda yapılan araştırmalar arasında en merak uyandıran olanı İskemik Önkoşullamadır (Ï̈̈K). Kısa bir zaman dilimi içerisinde gerçekleşen iskemi-reperfüzyon (i/R) ataklarının sonrasında, miyokardiyumu, daha sonraki asıl gerçekleşecek olan İ/R hasarına karşı dayanıklı hale getirdiği ve koruyucu etkisinin olduğu görülmüştür ve "İskemik Önkoşullama" olarak adlandırılmıştır (Murry ark., 1986). İlk olarak 1986 yllında Murry tarafından köpek myokardı üzerindeki koruyucu etkisiyle keşfedildikten sonra bilim adamlarının dikkatini çekmeyi başarmış bir olgudur.

İskemik Önkoşullama kalp krizi ya da perioperatif süreçler gibi özellikle organların zarar görmesine ve organlarda hücresel hasara karşı korumak için yapılan çalışmaların derinliği artmıştır. İlk çalışmalar kalp dokusu üzerinde yapıldıktan sonra İÖK'nın hücre düzeyindeki mekanizması ve koruyucu etkisi farklı doku tiplerinde de araştııılmaya başlanmıştır (Hutter ark., 1994). Neely ve Keith kedi akciğeri üzerinde olumlu etkisinin olduğu geri bildiriminde bulunmuşlardır (Neely ve Keith, 1995). Ayrıca farklı çalışmalarda transplate böbrekte (Redaelli ark., 2002) ve karaciğerde (Fernandez ark., 2003) de koruyucu bir etkisinin olduğunu göstermiştir. Kimura ark., (2007) tekrarlı iskemik önkoşullama uygulamasının nitrik oksitteki artış ile arteryal endotelyal fonksiyonun arttığını bildirmişlerdir (Kimura vd., 2007). İskemik önkoşullamanın mekanizması hücresel düzeyde tam olarak bilinmesede, protein kinaz C aktivasyonu, adenosin reseptör uyarılması ve ATP' ye bağımlı potasyum kanallarının aktive olmasında önemli etkisi olduğu düşünülmektedir (Baines ark., 1997).

Bu bulgulara dayanarak, İÖK egzersiz kapasitesi ve performansını geliştirmek için yeni bir müdahale yöntemi olarak spor bilimcilerin ilgisini uyandırmıştır (De Groot ark., 2010; JeanSt ark., 2011). Bu yöntem pahalı olmadığı ve kolaylıkla uygulanabilir olduğu için, egzersiz performansını arttırmak, müsabaka ve yarışlarda avantaj sağlamak isteyen sporcular için ilgi çekici bir yöntem olarak uygulanmaya çalışılmaktadır (Clevidence ark., 2012; Foster ark., 2011; Jean-St ark., 2011). Yapılmış olan birçok çalışmada iskemik önkoşullamanın sporcularda laboratuvar ortamında kas gücü ve kinematiği ile ilişkisinin etkileri ortaya konulmaya çalışılmasına rağmen, akut etkileri konusunda farklı bulgu ve sonuçlar ortaya konmuştur.

\section{İskemik Önkoşullama ve Egzersiz Performansini Etkileyen Değişkenler}

Yakın zamanda yapılan birçok çalışmada incelenen IÖ̈$_{\mathrm{K}}{ }^{\prime}$ nın egzersiz performansı ve kapasitesini olumlu ve olumsuz yönde etkileyen değişkenlerin olduğu gözlenmiştir (Kjeld ark., 2014; Cruz ark., 2015; Hittinger ark., 2015; Paixa 〜O ark., 2014). Bu değişkenler yaş, cinsiyet, kondisyon durumu, egzersizin yoğunluğu ve türü, uygulanan İÖК protokolü, ayrıca iskemi/reperfüzyon siklus sayısı, uygulanan bölgeler, iskemi/reperfüzyonun uygulandığı kas kitlelerindeki farklılıklar, iskemik önkoşullama sonrası egzersize başlama optimal zaman aralığı gibi. Bütün bu değiş̧kenleri göz önünde bulundurduğumuzda, İÖ ${ }_{K}$ uygulamasının en iyi yöntemi tam olarak bilinmemektedir. 


\section{İskemik Önkoşullama ve Spor Biliminde Uygulanışı}

Literatürleri incelediğimizde, iskemik önkoşullamanın egzersiz kapasitesi ya da performansı üzerindeki etkilerini araştıran 26 çalışmanın ayrı ayrı incelenmesi sonucunda çalışma sürecine dahil edilmişlerdir. Genellikle İÖK protokolleri, $220 \mathrm{mmHg}$ yada sistolik kan basıncı üzerinde $+15,+20,+40,+50 \mathrm{mmHg}$ basınç seviyesinde 5 dakikalık döngüsel oklüzyonun iki, üç ya da dört döngüsünü kapsamış ve bu süreci 5 dakikalık bir reperfüzyon süresi takip etmiştir. Manşon basıncına bağlı nöromusküler hasarın olmaması için olabildiğince geniş olan manşon tercih edilmiştir ve arteriyel kan akımını kesen minumum basınç kullanılmıştır (Moore ark., 1987; Ochoa ark., 1972). Ayrıca çalışma öncesinde katılımcılar tarafından kafein, alkol, sigara ve ergonejik yardım vb. gibi maddelerin alınmaması ve herhangi bir sportif faaliyette bulunmamaları istenmiştir (Gibson ark., 2013; Gibson ark., 2015)

Tablo 1. İskemik önkoşullamanın spor bilimlerinde uygulanış protokolleri

\section{Protokollerin Uygulanışı}

1. Turnike basıncı sistolik kan basıncından $+15,+20,+40,+50 \mathrm{mmHg}$ yada $220 \mathrm{mmHg}$ üstünde basınç seviyesi

2. 2,3,4 yada 5 sefer 5 dakikalık oklüzyon ve reperfüzyon döngüsü

3. Çift ya da tek taraflı olamak üzere üst kol ya da bacak bölgesi

4.Testler öncesi kafein, alkol, ergonejik yardım gibi maddelerin kullanılmaması

\section{İskemik Önkoşullama Uygulamasında Popülasyonunun Belirlenmesi}

Geçmişte yapılan iskemik önkoşullamanın egzersiz performansı üzerine etkisini araştıran 26 makalede çalışmalara katılımı sağlanan denek grupları iki şekilde oluşturulmuştur. 15 çalışmada (Bailey ark., 2012; Baines ark., 1997; Cruz et at., 2015; Ferreira ark., 2016; Gibson ark., 2013; Gibson ark., 2015; Gürses ark., 2018;. Jean-St ark., 2011, Lalonde ve Curnier, 2015; Marocolo ark., 2015; Marocolo ark., 2016; Patterson ark., 2015; Paixa O ark., 2014; Tanaka ark., 2016; Tocco ark., 2015) denek grubunun yanında kontrol grubu da kullanılırken, 11 çalışmada (Baikoğlu ve Kaldırımcı, 2019; Clevidence ark., 2012; Crisafulli ark., 2011; De Groot ark., 2010; El Messaoudi ark., 2013; Foster ark., 2011; Hittinger ark., 2015; Jones ark., 2015; Kido ark., 2015; Kjeld ark., 2014; Paradis-Deschênes ark., 2017) denek grupları ile randomize şekilde çalışıldığ 1 görülmüştür. 26 çalışmanın toplamında 405 denek (312 erkek, 93 kadın) kullanılmıştır. Ayrıca incelemeye aldığımız 26 çalışmanın oluşturulan denek gruplarına bakıldığında 13 çalışmada (Clevidence ark., 2012; Cruz ark., 2015; Foster ark., 2011; Gibson ark., 2015; Gürses ark., 2018; Hittinger ark., 2015; Jean-St ark., 2011; Kjeld ark., 2014; Morocolo ark., 2016; Paixa O ark., 2014; ParadisDeschênes ark., 2017; Patterson ark., 2015; Tocco ark., 2015) amatör ve profesyonel sporcular (yüzücüler, maratoncular, badmintoncular, bisikletçiler vb.), 13 çalışmada ise ( Baikoğlu ve Kaldırımcı, 2019; Bailey ark., 2012; Barbosa ark., 2015; El Messaoudi ark., 2013; Jones ark., 2015; Kido ark., 2015; Lalonde \& Curnier, 2015; Morocolo ark., 2015; Tanaka ark., 2016; Gibson ark., 2013; De Groot ark., 2010; Crisafulli ark., 2011; Ferreira ark., 2016 ) gönüllü olan sağlıklı sedanter bireylerden seçilmiştir. İskemik önkoşullamanın performans üzerine etkisini incelerken uygulanan performans test 
sonuçlarının popülasyon farklılıklarından ötürü değişkenlik gösterebileceği de düşünülmektedir.

\section{İSKEMİK ÖNKOŞULLAMANIN UYGULANDIĞI BÖLGELER}

İskemik önkoşullama ile egzersiz performansı arasındaki ilişkiyi inceleyen daha önceki çalışmaların çoğunda, İÖK protokolünde uygulama alanı olarak farklı bölgeler tercih edilmiştir. Literatür taramalarının sonucu olarak 6 çalışmada (El Messaoudi ark., 2013; Jean-St ark., 2011; Jones ark., 2015; Kjeld ark., 2014; Lalonde \& Curnier, 2015; Morocolo ark., 2015) bilateral yada unilateral üst kol, 14 çalışmada ( Baikoğlu ve Kaldırımc1, 2019; Bailey ark., 2012; Barbosa ark., 2015; Crisafulli ark., 2011; Cruz ark., 2015; De Groot ark., 2010; Ferreira ark., 2016; Gürses ark., 2018; Hittinger ark., 2015; Kido ark., 2015; Paixa ${ }^{O} \mathrm{O}$ ark., 2014; Patterson ark., 2015; Tanaka ark., 2016; Tocco ark., 2015) bilateral üst bacak ve 6 çalışmada ise (Clevidence ark., 2012; Ferreira ark., 2016; Foster ark., 2011; Gibson ark., 2013; Gibson ark., 2015; Morocolo ark., 2016) unilateral üst bacak bölgelerinde uygulama yapılmıştır. İlk yapılan çalışmalarda küçük kas gruplarında kısa süreli iskemiler yaratılarak yapılmış olmasına rağmen, daha sonraları daha büyük kas kitleleri içeren uzun süreli çok tekrarlı çalışmalar uygulanmaya başlanmıştır.

\section{ISKKEMIK ÖNKOŞULLAMANIN ÜST EKSTREMITEYE UYGULANMASI}

Konuyla ilişkili olarak ilk etapta kü̧̧ük kas kitlelerinin dahil edildiği çalı̧̧maları incelenmiştir. Jean-St ark., (2011) gerçekleştirdiği çalışmada yüzücülerde tek kolla yaptıkları iskemi-reperfüzyon uygulaması sonrasında, 1. denek grubu (9 erkek ve 9 kadın yüzücü) 100 m. yüzme testine ve 2 . denek grubu ise ( 8 erkek ve 8 kadın elit yüzücü) $200 \mathrm{~m}$. interval yüzme testine tabii tutulmuştur. Çalışma sonucu olarak yüzücülerin kişisel performanslarında istatistiksel olarak anlamlı denebilecek artışların olduğu rapor edilmiştir (Jean-St vd., 2011). Küçük kas gruplarını içeren başka bir iskemi çalışmasında ise, 20 erkek ve 5 kadın dalgııın katılımıyla yapılmış olan tek taraflı üst kolda iskemi uygulamasının sonucu olarak yüzme mesafesinde artma sağlandığı ayrıca 1-km kürek çekme süresini ve statik nefes tutma süresini uzattı̆̆ını ortaya konulmuştur (Kjeld ark., 2014). Marocolo ark., (2015) İÖ̈ ${ }_{\mathrm{K}}$ uygulamasını denek grubunun yanında kontrol grubuyla karşılaştırarak yaptıkları çalışmada $100 \mathrm{~m}$. yüzme sprint süresini geliştirdiğini, fakat kontrol ve denek grupları arasında hiçbir farkın gözlemlenmediğini bildirmişlerdir. Bu da İÖK ${ }_{\mathrm{K}}$ ile sprint süresinde görülen bir iyileşmenin, sadece bir placebo etkisi olabileceği şeklinde düşündürmüştür (Marocolo ark., 2015).

Diğer çalışmaların sonuçlarından farklı olarak kolların dahil edildiği bir diğer çalışmada 6x6 saniyelik yapılan wingate test sonuçlarına göre iskemi-reperfüzyon uygulamasının koldaki egzersiz performansını geliştirmediği belirtilmiştir (Lalonde ve Curnier, 2015). Bu çalışmaların sonucunu destekler şekilde El Messaoudi ark., (2013) yükleme şeklinde yaptıkları submaksimal bisiklet test sonuçlarının da performans üzerinde olumlu etkisinin olmadığı geri bildiriminde bulunmuşlardır (El Messaoudi ark., 2013).

Yapılan çalışmaların genelinde İÖ$_{\mathrm{K}}{ }^{\prime}$ nın egzersiz performansı üzerindeki akut etkileri incelenmiştir. İ̈̈ ${ }_{K}^{\prime}$ nın egzersiz performansı üzerindeki kronik etkisini inceleyen tek çalışmada ise Jones ark., (2015) 8 haftalık yaptıkları egzersiz periyodu boyunca, unilateral üst kolda düzenli ve rutin bir şekilde oluşturulan İ̈̈ ${ }_{\mathrm{K}}$ nın, aerobik fitnesda olumlu gelişmeler yaratmadığını bildirmişlerdir. Yakın zamanda yapılan bu çalışma, tekrarlı İÖ'nin vasküler 
fonksiyon üzerindeki etkilerine odaklandığı için, egzersiz performansına yönelik detaylı sonuçları değerlendirilmemiştir (Jones ark., 2015).

Tablo 2. İskemik önkoşullamanın üst ekstremiteye uygulanan çalışmalar

\begin{tabular}{|c|c|c|c|}
\hline $\begin{array}{l}\text { İncelenen } \\
\text { Çalışmalar }\end{array}$ & Denek grubu & Uygulanan bölge & Performans üzerine etkisi \\
\hline Jean-St vd., 2011 & $\begin{array}{l}9 \text { kadın, } 9 \text { erkek } 100 \\
\text { m. yüzücü, } 8 \text { erkek, } \\
8 \text { kadın } 200 \text { m. elit } \\
\text { yüzücü }\end{array}$ & Bilateral üst kol & Yüzme performansında artış \\
\hline Kjeld vd., 2014 & $\begin{array}{l}20 \text { erkek, } 5 \text { kadın } \\
\text { Dalgıç }\end{array}$ & Bilateral Üst Kol & $\begin{array}{l}\text { Yüzme mesafesinde artış, 1-km kürek } \\
\text { çekme süresi ve statik nefes tutma } \\
\text { süresinde artış }\end{array}$ \\
\hline $\begin{array}{l}\text { Marocolo vd., } \\
2015\end{array}$ & $\begin{array}{l}15 \text { erkek amatör } \\
\text { yüzücü }\end{array}$ & Unilateral üst kol & Performans sabit \\
\hline $\begin{array}{l}\text { El Messaoudi vd., } \\
2013\end{array}$ & $\begin{array}{l}10 \text { erkek,10 kadın } \\
\text { sağlıklı katılımcı }\end{array}$ & Bilateral üst kol & Performans sabit \\
\hline $\begin{array}{l}\text { Lalonde \& } \\
\text { Curnier, 2015) }\end{array}$ & $\begin{array}{l}8 \text { erkek, } 9 \text { kadın } \\
\text { sağlıklı katılımcı }\end{array}$ & Bilateral Üst Kol & $\begin{array}{l}\text { Zirve güç ve ortalama egzersiz } \\
\text { performans1 sabit }\end{array}$ \\
\hline Jones vd., 2015 & $\begin{array}{l}18 \text { erkek sağlıklı } \\
\text { katılımcı }\end{array}$ & Unilateral üst kol & Aerobik fitnes performansı sabit \\
\hline
\end{tabular}

\section{İSKEMIK ÖNKOŞULLAMANIN ALT EKSTREMITEYE UYGULANMASI}

Yapılan küçük kas kitlesinin dahil edildiği üst kol çalışmalarının haricinde alt ekstremitelerin tek taraflı şekilde dahil edildiği çalışmalara odaklanılmıştır. Foster ark., (2011) alt ektremitede unilateral üst bacakta yaratılan iskeminin performans üzerine etkisini araştırmış ve olumlu bir etkinin gelişmediğini rapor etmişlerdir (Foster ark., 2011). Yapılmış olan bu çalışmayı benzer şekilde destekleyen başka bir çalışmada ise üst bacak femoral bölgede tek taraflı iskemi oluşturduktan sonra bisiklet testi uygulanmış, fakat aerobik ve anaerobik performansta olumlu bir etkinin oluşmadığı rapor edilmiştir (Clevidence ark., 2012). Gibson ark., (2015) ilk çalışmalarında 16 erkek ve 9 kadın sağlıklı katılımcıya tek taraflı uygulanan $3 \times 5$ dakika $220 \mathrm{mmHg}$ basınçta döngüsel iskemi oluşturmuşlardır. Çalışma sonucu olarak İÖ ${ }_{K}^{\prime} \quad$ nın egzersiz performansına önemli bir etkisinin olmadığı geribildiriminde bulunmuşlardır. Bununla beraber, bayan katılımcılarda küçük ve olumsuz bir etki gözlendiğini bildirilmiştir (Gibson ark., 2013). Bunun üzerine daha sonraki y1llarda Gibson vd., .'nın gerçekleştirdikleri ikinci çalışmalarında takım sporlarında yer alan 16 sporcuda iskemik önkoşullamanın etkisini tekrardan araştırmışlardır. Test protokolü olarak 24 saniyelik dinlenmeler verilerek deneklere $5 \times 6$ saniye hızlı koşular yaptırmışlardır. Çalışma sonucunda pik tork ve toplam iş gücü değerlerinde değişiklik görülmediğini bildirmişlerdir (Gibson ark., 2015). Maracola ark., (2016) 13 erkek üzerinde yaptıkları farklı bir çalışmalarının sonucunda performans değerinde ve laktat seviyelerinde bir değişiklik olmadığını yorumlamışlardır (Marocolo ark., 2016).

Diğer çalışma sonuçlarına zıt bir şekilde Paris- Deschênes ark., (2017) güç arttırıcı egzersizler yapan 8 erkek ve 9 kadın katılımcı ile gerçekleştirdikleri çalışmalarında sürekli maksimal kontraksiyonlar (kasılmalar) esnasında performans, ve İÖ ${ }_{\mathrm{K}}$ ' ya vazoaktif (damar etkin) ve oksidatif tepkilerin cinsiyete göre etkilerini incelemişlerdir. Bu çalışmada tek taraflı 
sağ bacak uyluk bölgesine yerleştirilen manşon basıncı aracıllğıyla İ/R döngüsü yaratarak test protokolünü oluşturmuşlar ve kontrol grubu ile karşılaştırmışlardır. Çalışmalarının sonucu olarak, kas gücünün erkelerde kadınlardan daha fazla arttığı, dinlenik kan basıncı her iki cinsiyet için benzer oranda arttığı ve oksijen salınımının erkeklerde artarken kadınlarda bu etkinin azaldığını rapor etmişlerdir (Paradis-Deschênes ark., 2017).

Ortaya konulmuş olan bu farklı sonuçlar doğrultusunda iskeminin performans yönündeki etkisini araştırmak için daha büyük kas gruplarını iskemik önkoşullandırma sürecine dahil edilmesi gerekliliği ileri sürülmüştür. İlk olarak her iki alt ekstremite femoral bölgesinde çalı̧ma yapan De Groot ark., (2010) bacaklarda sırayla dönüşümlü olarak tekrarlayan iskemi/reperfüzyon dögüsünü gerçekleştirmişlerdir. Çalışma sonunda, maksimum tüketilen oksijen değerleri ve $1.6 \%$ lık bir maksimal güç çıkışında olumlu bir artı̧ olduğunu ileri sürmüşlerdir (De Groot ark., 2010). Benzer bir yöntem kullanarak gerçekleştirilmiş olan başka bir araştırmada Crisafulli ark., (2011) deneklerin üst bacak femoral bölgesinde dönüşümlü olmak üzere iskemi oluşturmuş fakat araştırmanın sonucu olarak maksimum tüketilen oksijen değerinde artış olmazken maksimum yaptıkları iş yükünde artış sağladıklarını bildirmiş̧lerdir (Crisafulli ark., 2011). Diğer yandan, günümüze yakın bir başka çalışmada ise araştırmacılar İÖ${ }_{\mathrm{K}}^{\prime}$ nın $50 \mathrm{~m}$. yüzme sprint performansını iyileştirdiğini fakat kan laktat seviyesinde pozitif yönde bir değiş̧im olmadığı geri bildiriminde bulunmuşlardır (Ferreira ark., 2016). Bailey ark., (2012) İ̈̈ ${ }_{\mathrm{K}}^{\prime}$ nın 5 km.' lik koşu bandı koşma süresini arttırdığını ve submaksimal koşu bandı koşulları boyunca kan-laktat birikmesinin azalttığını çalışmalarının sonucu olarak belirtmişlerdir (Bailey ark., 2012). Patterson ark., (2015) 14 erkek sporcuyla birlikte yaptıkları 6 tekrar 12 saniyelik sprint testinin sonucunda ortalama

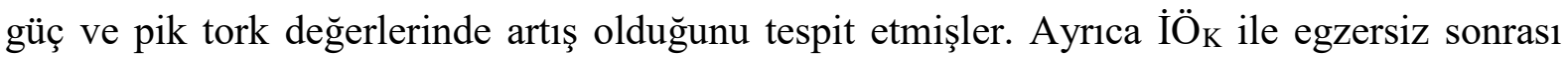
kan laktat değerlerinde hiçbir etki farklılığı görmemişlerdir (Patterson ark., 2015). Bilateral üst bacakta uygulanan farklı çalışmalarda iskeminin performansa etkisinin sonucunda egzersizi bırakma sürelerinde artışların olduğunu bildirmiş̧lerdir (Cruz ark., 2015; Kido ark., 2015).

Barbosa ark., (2015) çalışmasında denek grubunun yanında kontrol grubu kullanarak bilateral üst bacakta iskemik önkoşullamanın egzersiz prformansı üzerine etkisini araştırmışlardır. Bacaktaki uzak İÖK'nın ise \%4 yoğunluklu (MVC) ritmik handgrip egzersizi boyunca, egzersizi bırakma süresini anlamlı derecede iyileştirdiğini göstermesine rağmen inceledikleri kan akışı, vasküler kondüktans gibi fizyolojik değişkenlerde anlamlı bir farklılık gözlemlememişlerdir (Barbosa ark., 2015). Yakın zamanda yapılan başka bir çalışma da İÖK'nın statik bacak ekstansiyonu egzersizi üzerindeki etkilerini incelemişlerdir. Çalışmalarının sonucunda egzersizi bırakma süresinin, kontrol grubuyla kıyaslandığında, iskemi uygulanan denek grubunda egzersizi bırakma süresinin anlamlı düzeyde daha fazla olduğu geri bildiriminde bulunmuşlardır. Ayrıca, izometrik bacak ekstansiyonu boyunca EMG de hiçbir farklılık görülmemişlerdir (Tanaka ark., 2016).

Bilateral üst bacakta incelediğimiz çalışmaların iskemik önkoşullamanın fiziksel performansa olan olumlu etkisinin yanı sıra aksi yönde de geri bildirimler olmuştur. Paxio O ark., (2014) çalışmasında wingate testi boyunca, IÖ̈${ }_{\mathrm{K}}^{\prime}$ nın zirve güç çıktısını ve total anaerobik güçte azalma olduğunu gözlemlemişlerdir (Paixa $O$ ark., 2014). Zirve güç parametresinde düşüşü destekleyen başka bir çalışmada Hittinger ark., (2015) 15 triatloncunun her iki bacağın üst 
kısmına iskemi oluşturarak elde ettikleri veriler doğrultusunda anaerobik performansı iyileştirmediğini bir kez daha ortaya koymuşlardır. Tocco ark., (2015) randomize şekilde oluşturdukları denek ve sham grubuna uygulanan iskemi-reperfüzyon periyodunun ardından yapılan $5 \mathrm{~km}$ koşu test sonuçlarının koşu süresinde herhangi bir gelişme yaratmamış olmasının yanı sıra 5 km' lik koşu esnasında ortalama akciğer ventilasyonu üzerinde de hiçbir etkisinin olmadığını rapor etmişlerdir. Ayrıca egzersiz sonrası kan-laktat değerinin anaerobik kapasitenin bir göstergesi olabileceği için incelemeye almışlar fakat hiçbir etki farkllılığı gözlemlememişlerdir.

Ülkemizde yapılan çalışmalara yöneldiğimizde, Gürses ark., (2018) badmintoncularda İÖK'nın yaratacağ 1 etkiyi incelemişler ve sporcuların performanslarında düşüş olduğunu bununla birlikte tekrarlar arası dinlenmede toparlanma üzerine de etkisi olmadığı geribildiriminde bulunmuşlardır. Baikoğlu ve Kaldırımcı (2019) çalışmasında farklı bir uygulama yöntemi kullanarak her iki üst bacakta aynı anda 5 dakikalık iskemi-reperfüzyon döngüsü gerçekleştirmişlerdir. Çalışmanın sonucu olarak, iskemi-reperfüzyon uygulamalarının anaerobik güç değerlerinde herhangi bir değişikliğe yol açmadığı gibi, ayrıca özellikle 3. dakika laktik asit değerlerinde anlamlı olmayan yükselmelere yol açmış olmasına rağmen bu etkinin zamansal seviyede çok belirgin artışa sebep olmadığını bildirmişlerdir.

Tablo 3. İskemik önkoşullamanın alt ekstremiteye uygulanan çalışmalar

\begin{tabular}{|c|c|c|c|}
\hline İncelenen Çalışmalar & $\begin{array}{l}\text { Uygulanan Denek } \\
\text { Grubu }\end{array}$ & Uygulanan Bölge & Performans Üzerine Etkisi \\
\hline Foster ve ark., 2011 & $\begin{array}{l}6 \text { erkek, } 2 \text { kadın } 10 \text { yıl } \\
\text { deneyimli bisikletçi }\end{array}$ & Unilateral üst bacak & Performans sabit \\
\hline Clevidence ve ark., 2012 & 27 erkek amatör bisikletçi & Unilateral üst bacak & Performans sabit \\
\hline Gibson ve ark., 2013 & $\begin{array}{l}16 \text { erkek, } 9 \text { kadın sağlıklı } \\
\text { katılımcı }\end{array}$ & Unilateral üst bacak & Zirve güç ve toplam iş gücü sabit \\
\hline Gibson vd., 2015 & $\begin{array}{l}7 \text { erkek, } 9 \text { kadın takım } \\
\text { sporcusu }\end{array}$ & Unilateral üst bacak & $30 \mathrm{~m}$. sprint süresi sabit \\
\hline Marocolo vd., 2016 & 13 erkek sağlıklı katılımcı & Unilateral üst bacak & Performans ve LA seviyesi sabit \\
\hline Paradis-Deschênes vd., 2017 & 8 erkek, 9 kadın sporcu & Unilateral üst bacak & Kas gücünde artış \\
\hline De Groot ark., 2010 & $\begin{array}{l}12 \text { erkek, } 3 \text { kadın sağlıklı } \\
\text { katılımcı }\end{array}$ & Bilateral üst bacak & $\mathrm{VO}_{2 \max } \operatorname{art} 1 s ̧, \mathrm{~W}_{\text {peak }}$ artış \\
\hline Crisafulli ark., 2011 & 17 erkek sağlıklı katılımcı & Bilateral üst bacak & $\mathrm{VO}_{2 \text { max sabit, }}$ Max. iş yükünde artış \\
\hline Ferreira ark., 2016 & $\begin{array}{l}16 \text { erkek, } 14 \text { kadın sağlıklı } \\
\text { katılımcı }\end{array}$ & Bilateral üst bacak & $\begin{array}{l}\text { Yüzme performansında artış, LA } \\
\text { seviyesi sabit }\end{array}$ \\
\hline Bailey ark., 2012 & 13 erkek sağlıklı katılımcı & Bilateral üst bacak & $\begin{array}{l}\text { Koşma süresinde artış, LA } \\
\text { seviyesinde düşme }\end{array}$ \\
\hline Patterson ark., 2015 & 14 erkek sporcu & Bilateral üst bacak & $\begin{array}{l}\text { Güç ve pik tork değerlerinde artış, } \\
\text { LA seviyesi sabit }\end{array}$ \\
\hline Cruz et at., 2015 & 12 erkek bisikletçi & Bilateral üst bacak & Egzersizi bırakma süresinde artış \\
\hline Kido ark., 2015 & 15 erkek sağlıklı katılımcı & Bilateral üst bacak & Egzersizi bırakma süresinde artış \\
\hline Barbosa ark., 2015 & 13 erkek sağlıklı katılımcı & Bilateral üst bacak & Egzersizi bırakma süresinde artış \\
\hline Tanaka ark., 2016 & 12 erkek sağlıklı katılımcı & Bilateral üst bacak & Egzersizi bırakma süresinde artış \\
\hline Paixa O ark., 2014 & 15 erkek bisikletçi & Bilateral üst bacak & $\begin{array}{l}\text { Zirve güç ve toplam güç } \\
\text { değerlerinde düşüş }\end{array}$ \\
\hline Hittinger ark., 2015 & 15 erkek triatloncu & Bilateral üst bacak & Zirve güç değerinde düşüş \\
\hline Tocco ark., 2015 & 11 erkek sporcu & Bilateral üst bacak & $\begin{array}{l}\text { Koşu süresi sabit, LA seviyesi } \\
\text { sabit }\end{array}$ \\
\hline Gürses ark., 2018 & $\begin{array}{l}16 \text { erkek, } 6 \text { bayan } \\
\text { badmintoncu }\end{array}$ & Bilateral üst bacak & Performans sabit \\
\hline Baikoğlu ve Kaldırımcı, 2019 & 14 erkek sağlıklı katılımcı & Bilateral üst bacak & $\begin{array}{l}\text { Performans sabit, LA seviyesi } \\
\text { sabit }\end{array}$ \\
\hline
\end{tabular}




\section{TARTIŞMA ve SONUÇ}

Çalışmamızın amacı doğrultusunda İÖ⿻' nın egzersiz kapasitesi ya da egzersiz performansı üzerine sağladığı katkıyı ve oluşabilecek fizyolojik tepkileri inceleyen çalışmaları bir bütün halinde toplamaya odaklandık. Yapılmış olan birçok çalışmada iskemik önkoşullamanın sporcularda laboratuvar ortamında kas gücü ve kinematiği ile ilişkisinin etkileri ortaya konulmaya çalışılmasına rağmen, akut etkileri konusunda farklı bulgu ve sonuçlar ortaya konulmuştur. İskemik önkoşullama yönteminde kasılma mekanizmalarında özellikle reperfüzyon sonrasında ortaya çıkan mekanizmalar ve bunların kas kuvveti üzerine olan etkileri üzerine çalışılmıştır. İncelediğimiz 26 çalışmanın 9 tanesinde İÖ'n’n egzersiz performansı üzerinde istatistiksel yönden anlamlı faydalar sağladığı sonucuna ulaşılmıştır. Örneğin, performansta artış, ortalama güç ve pik tork değerlerinde artış, artan enerji çıkış1 ya da algılanan eforda azalma gibi. Yine de bu pozitif bulgulara rağmen, 17 çalışmanın sonucu olarak da, İ̈̈' nın egzersiz performansı üzerinde hiçbir etkisinin olmadığı raporlarla sunulmuştur. Tekrarlanan iskemi-reperfüzyon döngülerinin damar düzeni üzerinde faydalı etkilerinin olabileceğinin farkına varan araştırmacılar bu durumun egzersiz performansında da olumlu sonuçlanabileceğini düşünerek hareket etmişlerdir. Fakat yapılan çalışmaların sonuçlarına bakarak İskemik önkoşullamanın sporcuların gerek aerobik gerekse anaerobik egzersiz performansları üzerindeki etkilerini daha iyi anlamak için, daha kontrollü ve mekanizmaları test edebilen çalışmalara gereksinim olduğu yadsınmaz bir gerçektir. Genel olarak yapılan çalışmalara bakıldığında İÖ ${ }_{K}$ ile ilgili değişikliklerin daha doğru tespiti için yapılan çalışmalarda kullanılan denek seçimlerindeki çeşitliliğinde ve örneklem boyutlarında artış yapılması gerektiğide düşünülmektedir. Ayrıca sporcuların bireysel seviyelerine uygun olacak şekilde İÖ ${ }_{K}$ protokolleri ve egzersiz yöntemleri oluşturulmalıdır. Buna ek olarak, bireysel fitness seviyeleri ve geçmiş spor deneyimleri, bu faktörlerin İÖ${ }_{\mathrm{K}}{ }^{\prime}$ nın etkililiğinde rol oynayıp oynamadıklarını tespit etmek ve potansiyel İÖK' ya tepki veren ve vermeyen fenotipleri daha iyi anlamak için, doğrudan karşılaştırmaların yapılması gereklidir.

Gelecekteki İÖ ${ }_{\mathrm{K}}$ çalışmaları çalışma sırasında fizyolojik mekanizmalara ait bilgileri arttırıcı yönde olmalıdır. Performansı arttırmaya yönelik olacak İÖ ${ }_{K}$ protokolleri geliştirilmesi ve İÖ ile egzersizin başlaması arasında optimal zaman aralığının belirlenmesi gerekmektedir. IÖ̈'nın uygulanabilirliği konusunda pratik ve kolaylaştırıcı yöntemler tespit edilmesine odaklanılmalıdır. Ayrıca denek ve kontrol grubunun aynı anda işleme alındığı İÖ uygulamalarının da sonuç güvenirliği açısında çalışma sayısının arttırılması gerekmektedir. Genel olarak, mevcut kanıtlar değerlendirildiğinde sporcuların aerobik ve anaerobik olarak performanslarını arttırmada İ̈̈ ${ }_{\mathrm{K}}$ ' nın uygulanabilirliği, ümit vericidir fakat daha fazla araştırmaya gereksinim olduğu da yadsınmaz bir gerçektir.

\section{KAYNAKLAR}

Baikoğlu, S. ve Kaldırımcı, M. (2019). Effect of 1schemıc pre-conditıonıng on lactate and anaerobıc performance. Acta Medica Mediterranea, 35, 159-164.

Bailey, T.G., Birk, G.K., Cable, N.T., Atkinson, G., Green, D.J., Jones, H. \& Thijssen, D.H. (2012). Remote ischemic preconditioning prevents reduction in brachial artery flowmediated dilation after strenuous exercise. Am J Physiol Heart Circ Physiol, 303, 533-538. 
Baines, C.P., Goto, M. \& Downey, J.M. (1997). Oxygen radicals released during ischemic preconditioning contribute to cardioprotection in the rabbit myocardium, J Mol Cell Cardiol, 29, 207-216.

Barbosa, T.C., Machado, A.C., Braz, I.D., Fernandes, I.A., Vianna, L.C., Nobrega, A.C. \& Silva, B.M. (2015). Remote ischemic preconditioning delays fatigue development during handgrip exercise. Scand $\mathrm{J}$ Med Sci Sports, 25, 356-364.

Clevidence, M.W., Mowery, R.E. \& Kushnick, M.R. (2012). The Effects of ischemic preconditioning on aerobic and anaerobic variables associated with submaximal cycling performance. Eur J Appl Physiol, 112, 3649-3654.

Crisafulli, A., Tangianu, F., Tocco, T., Concu, A., Mameli, O., Mulliri, G. \& Caria, M.A. (2011). Ischemic preconditioning of the muscles improves maximal exercise performance but not maximal oxygen uptake in humans. J Appl Physiol, 111, 530-536.

Cruz, R.S., De Aguiar, R.A., Turnes, T., Pereira, K.L. \& Caputo, F. (2015). Effects of ischemic preconditioning on maximal constant load cycling performance. J Appl Physiol, 119, 961-967.

De Groot, P., Thijssen, D., Sanchez, M., Ellenkamp, R. \& Hopman, M.T. (2010). Ischemic preconditioning improves maximal performance in humans. Eur J Appl Physiol, 108, 141-146.

El Messaoudi, S., Vissers, A., Thijssen, D., Riksen, N.P. \& Rongen, G.A. (2013). The effect of remote ischemic preconditioning on exercise-induced plasma troponin i appearance in healthy volunteers. Int J Cardiol, $168,1612-1613$.

Fernandez, L., Heredia, N., Peralta, C., Xaus, C,, Rosello-Catafau, J., Rimola, A., Marco, A., Serafin, A., Deulofeu, R., Gelpi, E. \& Grande, L. (2003). Role of ischemic preconditioning and the portosystemic shunt in the prevention of liver and lung damage after rat liver transplantation. Transplantation, 76, 282-289.

Ferreira, T.N., Sabino-Carvalho, J.L., Lopes, T.R., Ribeiro, I.C., Succi, J.E., Da Silva, A.C. \& Silva, BM. (2016). Ischemic preconditioning and repeated sprint swimming: A Placebo and nocebo study. Med Sci Sports Exerc, 48, 1967-1975.

Foster, G.P., Westerdahl, D.E., Foster, L.A., Hsu, J.V. \& Anholm, J.D. (2011). Ischemic preconditioning of the lower extremity attenuates the normal hypoxic increase in pulmonary artery systolic pressure. Respir Physiol Neurobiol, 179, 248-253.

Gibson, N., White, J., Neish, M. \& Murray, A. (2013). Effect of ischemic preconditioning on land-based sprinting in team-sport athletes. Int J Sports Physiol Perform, 8, 671-676.

Gibson, N., Mahony, B., Tracey, C., Fawkner, S. \& Murray A. (2015). Effect of ischemic preconditioning on repeated sprint ability in team sport athletes. J Sports Sci, 33, 1182-1188.

Gürses, V.V., Kerem, M., Akgül, M.Ş., Ceylan, B. ve Baydil, B. (2018). Badmintoncularda iskemik önkoşullamanın yüksek şiddetli interval performans ve toparlanma üzerine etkisinin incelenmesi. Sportif Bakış: Spor ve Ĕgitim Bilimleri Dergisi, 5, 20-32.

Hittinger, E.A., Maher, J.L. \& Nash, M.S. (2015). Ischemic preconditioning does not improve peak exercise capacity at sea level or simulated high altitude in trained male cyclists. Appl Physiol Nutr Metab, 40, 65-71.

Hutter, M.M., Sievers, R.E., Barbosa, V. \& Wolfe, C.L. (1994). Heatshock protein induction in rat hearts. a direct correlation between the amount of heat-shock protein induced and the degree of myocardial protection. Circulation, 89, 355-360.

Jean-St, E., Manlhiot, C., Li, J., Tropak, M., Michelsen, M.M., Schmidt, MR., Mccrindle, B.W., Wells, G.D. \& Redington, A.N. (2011). Remote preconditioning improves maximal performance in highly trained athletes. Med Sci Sports Exerc, 43, 1280-1286. 
Jones, H., Nyakayiru, J., Bailey, T.G., Green, D.J., Cable, N.T., Sprung, V.S., Hopkins, N.D. \& Thijssen, D.H. (2015). Impact of Eight Weeks of Repeated Ischaemic Preconditioning on Brachial Artery and Cutaneous Microcirculatory Function in Healthy Males. Eur J Prev Cardiol, 22, 1083-1087.

Kido, K., Suga, T., Tanaka, D., Honjo, T., Homma, T., Fujita, S., Hamaoka, T. \& Isaka, T. (2015). Ischemic preconditioning accelerates muscle deoxygenation dynamics and enhances exercise endurance during the work-to-work test. Physiol Rep, 3, 12-39.

Kimura, M., Ueda, K., Goto, C., Jitsuiki, D., Umemura, T., Noma, K., Yoshizumi, M., Chayama, K. \& Higashi, Y. (2007). Repetition of ischemic preconditioning augments endothelium-dependent vasodilation in humans: role of endothelium-derived nitric oxide and endothelial progenitor cells. Arterioscler Thromb Vasc Biol, 27, 1403-1410.

Kjeld, T., Rasmussen, M.R., Jattu, T., Nielsen, H.B. \& Secher, N.H. (2014). Ischemic preconditioning of one forearm enhances static and dynamic apnea. Med Sci Sports Exerc, 46, 151-155.

Lalonde, F. \& Curnier, D.Y., (2015). Can anaerobic performance be improved by remote ischemic preconditioning?. J Strength Cond Res, 29, 80-85.

Marocolo, M., da Mota, G.R., Pelegrini, V. \& Appell Coriolano, H.J. (2015). Are the beneficial effects of ischemic preconditioning on performance partly a placebo effect? Int J Sports Med, 36, 822-825.

Marocolo, M., Willardson, J.M., Marocolo, I.C., da Mota, G.R., Simao, R. \& Maior, A.S. (2016). Ischemic preconditioning and placebo intervention improves resistance exercise performance. J Strength Cond Res, 30, 1462-1469.

Moore, M.R., Garfin, S.R. \& Hargens, A.R. (1987). Wide tourniquets eliminate blood flow at low inflation pressures. J Hand Surg Am, 12, 1006-1011.

Murry, C.E., Jennings, R.B. \& Reiber, K.A. (1986). Preconditioning With Ischemia: A Delay of lethal cell injury in ischemic myocardium. Circulation, 74, 1124-1136.

Neely, C.F. \& Keith, I.M. (1995). A1 Adenosine receptor antagonists block ischemia reperfusion injury of the lung. Am J Physiol, 268, 1036-1046.

Ochoa, J., Fowler, J.T. \& Gilliatt, W.T. (1972). Anatomical changes in peripheral nerves compressed by a pneumatic tourniquet. J Anat, 113, 433-455.

Paixa O, R.C., da Mota, G.R. \& Marocolo, M. (2014). Acute effect of ischemic preconditioning is detrimental to anaerobic performance in cyclists. Int J Sports Med, 35, 912-915.

Paradis-Deschênes, P., Joanisse, D.R. \& Billaut, F. (2017). Sex-specific impact of ischemic preconditioning on tissue oxygenation and maximal concentric force. Front Physiol, 7, 674-682.

Patterson, S.D., Bezodis, N.E., Glaister, M. \& Pattison, J.R. (2015). The Effect of ischemic preconditioning on repeated sprint cycling performance. Med Sci Sports Exerc, 47, 1652-1658.

Redaelli, C.A., Tien, Y.H., Kubulus, D., Mazzucchelli, L., Schiling, M.K. \& Wagner, A.C.C. (2002). Hyperthermia preconditioning induces renal heat shock protein expression, improves cold ischemia tolerance, kidney graft function and survival in Rats. Nephron, 90, 489-497.

Tanaka, D., Suga, T., Tanaka, T., Kido, K., Honjo, T., Fujita, S., Hamaoka, T. \& Isaka, T. (2016). Ischemic preconditioning enhances muscle endurance during sustained isometric exercise. Int J Sports Med, 37, 614-618.

Tocco, F., Marongiu, E., Ghiani, G., Sanna, I., Palazzolo, G., Olla, S., Pusceddu, M., Sanna, P., Corona, F., Concu, A. \& Crisafulli, A. (2015). Muscle ischemic preconditioning does not improve performance during self-paced exercise. Int J Sports Med, 36, 9-15. 